\title{
Slit Homolog 2 Protein
}

National Cancer Institute

\section{Source}

National Cancer Institute. Slit Homolog 2 Protein. NCI Thesaurus. Code C126787.

Slit homolog 2 protein (1529 aa, $170 \mathrm{kDa}$ ) is encoded by the human SLIT 2 gene. This protein is involved in the modulation of cell migration and the development of the nervous system. 